\title{
An Exception to European Epistemological Rule: The Representation of Indigeneity in the Works of Mudrooroo and Alan Duff
}

\section{Laura Singeot}

\section{(2) OpenEdition}

\section{Journals}

Electronic version

URL: http://journals.openedition.org/ces/4166

DOI: $10.4000 /$ ces. 4166

ISSN: 2534-6695

\section{Publisher}

SEPC (Société d'études des pays du Commonwealth)

\section{Electronic reference}

Laura Singeot, «An Exception to European Epistemological Rule: The Representation of Indigeneity in the Works of Mudrooroo and Alan Duff », Commonwealth Essays and Studies [Online], 43.1 | 2020 ,

Online since 06 November 2020, connection on 10 November 2020. URL : http:// journals.openedition.org/ces/4166; DOI : https://doi.org/10.4000/ces.4166

This text was automatically generated on 10 November 2020.

\section{cc) $(1) \odot$}

Commonwealth Essays and Studies is licensed under a Licence Creative Commons Attribution - Pas d'Utilisation Commerciale - Pas de Modification 4.0 International. 


\title{
An Exception to European Epistemological Rule: The Representation of Indigeneity in the Works of Mudrooroo and Alan Duff
}

\author{
Laura Singeot
}

1 Both Mudrooroo (the author of Master of the Ghost Dreaming series) and Alan Duff (who wrote Once Were Warriors) have been at the centre of controversies concerning their indigenous identity or their depiction of their own community: while in 1996, a journalist ${ }^{1}$ revealed that Mudrooroo's Aboriginal ancestry could not be confirmed, Duff was considered by part of his community as a traitor for exposing their darkest side, feeding on poverty, alcohol and violence. Those two examples show the difficulties native populations may encounter when trying to redefine their identity, since they have to fight against pre-existing Western assumptions about identity and belonging. As a consequence, Duff's and Mudrooroo's novels may be considered as counterdiscourses, but their epistemological strategy does not merely rely on a blunt opposition to Western discourses, which they acknowledge yet do not advocate. It is only by rendering visible those first hegemonic representations that they can question them, in order to renegotiate representations of Indigeneity.

2 Taking as its starting point Edward Said's The World, the Text and the Critic, in which he theorizes the cultural dynamics of filiation and affiliation, this article questions the epistemological links Mudrooroo's and Duff's works weave with European constructs of the Indigene. First, they appear to reject discursive filiation, or what can be called "epistemological localisms": as postcolonial literary works, they rewrite historically repressive colonial discourse, which is more often than not linked to the idea of filiation - either paternalistic, missionary or biological. Since this discourse is usually rooted in a specific environment or place, it stems from local systems of representation used by the power in place in colonized territories, relying on those very epistemological localisms to reassert its hegemony. This article will begin by examining 
the specific treatment of the father figure and colonial as well as racial discourses, leading to a questioning of assimilation and going against any notion of "discursive filiation": if these works rewrite such discourses, revolving around a father figure in the broad sense of the term, they do so in order to subvert it. Then, turning to the notion of affiliation will allow us to question the globalization of the epistemological systems at work in these novels, especially through the redefinition of the Indigenous cultural community. Finally, the reflection will consider the idea of "double consciousness" as it is displayed in the novels: they do acknowledge biased representations of the Indigenous figure, but, instead of taking part in the homogenisation and assimilation of culture, they examine and subvert those epistemological colonial traces while calling for self-definition.

\section{A case against filiation: rejecting epistemological localisms}

3 According to Edward Said, "the loss of the subject, as it has commonly been referred to, is in various ways the loss as well of the procreative, generational urge authorizing filiative relationships" (1983, 20). In other words, far from being considered an autonomous entity, the subject has to be considered according to its relation to others. As a matter of fact, the novels under scrutiny rely heavily on family ties, most specifically on filial ones, but it also seems as if their loss of subjectivity - or of subjects - goes hand in hand with the destruction of these links.

4 Father figures are the first ones to undergo the destruction of filial links; filial relationships are always perverted, sterile or even incestuous. The first example that comes to mind is the transitional moment in Once Were Warriors when Māori teenage girl Grace commits suicide because she thinks she has been raped multiple times by Jake, her father, as she writes in the letter her mother reads afterwards. However, if the second book of the trilogy (What Becomes of the Broken-Hearted?) starts with Jake's exculpation, on a metaphorical level, the harm has already been done: the father figure is repeatedly held guilty of having transmitted bad genes to his offspring, as well as the enduring perceived status of slave. This doomed legacy is inherited from Jake's ancestors who were shunned and had to live on the margins of their Pâ: ${ }^{2}$ in the story, it partly explains the family's present wretched situation, leading Jake's children to constantly hold him responsible for it. In one most disturbing image, the genealogical tree, instead of being a conventional tree of life, becomes the tree of death for Grace: the metaphorical family tree finds its physical counterpart in the tree overlooking the Tramberts' property, the one from which she jumps to hang herself. While the genealogical tree encapsulates the notion of continuity, transmitting life from one branch to the next, upwards, the Heke family tree loses one of them. Jake, considered as a monster, is exiled from his family, rejected by Beth and their children, typically embodying what David Punter wrote: "What is the secret of the family tree? Incest, says Freud" $(1998,201)$. Punter also argues that "the monster and the terrorist have no family; they have no family history, no family tree, and thus they are exiled" (205), just as Jake is exiled and becomes homeless and family-less, while his children claim that they are "fatherless."

5 In Once Were Warriors, the second consequence of the rejection of the father-figure is the children's hereditary anxiety, since they in no way want to repeat their father's 
mistakes. The notion of "stain" 3 is prevalent in those passages and is strongly associated to the ethnic and social context in which the Māori characters are evolving while at the same time harking back to racist ideology. None of the Māori youngsters can escape from it, as shown in the following passage which focuses on the young members of a gang:

Truth was (any kid could see) they wanted to hide in the volume of music like they were always hidin behind their shades or in the dope and the booze and the fags; they juss wanna drown out the, you know, the upbringing. The stain of growing up a Pine Blocker. Of growin up havin to fit a role, a race role [...]. (Duff 2004a, 141; emphasis added)

Contamination is directly linked to "race" and to what it implies in contemporary society, on the social level, for example having to rent a car because you could never dream of owning one, or living in state-owned houses for exactly the same reason. During the 1990s debate over the issues of tradition and authenticity in Pacific cultures, ${ }^{4}$ one of the Western constructions of the idea of ethnicity also relied on heredity, as Margaret Jolly explains: "Western constructs of ethnicity on the other hand create mutually bounded, stable entities based on ideas of innate shared substance - blood or seed" (1992, 59-60). As a consequence, Indigenous characters share that colonial and Western perception of Indigenous legacy as a flaw from which no one can be cured. That genetic determinism thus becomes an infernal epanorthotic cycle in Jake's Long Shadow: "It might be genes, could be genes, must be genes. No one can be nurtured to become that evil" (Duff 2002, 165).

7 On a cultural and historical level, these questions of heredity are often linked to that of assimilation. As a matter of fact, if Indigenous populations cannot fight against hereditary traits, it might mean that no matter how hard colonizers try to "civilize" them, they will always go back to their former savage selves, or "revert to type." In Duff, it seems that even the Māori characters share that way of thinking since they have come to conform to the racial construction imposed on them by society, mistaking it for scientific knowledge and thus confusing the question of race with that of genetic makeup. To them, being Māori explains their violent behaviour: "Must be something in the Maori make-up makes us wilder, more inclined to breaking the law" (Duff 2004a, 43). Māori are thus condemned to being influenced by their "racial" traits:

You could just see why these young warriors'd joined up with the Browns: it was love. Being loveless. As well as something else missing... but what was it...? Sumpthin to do with race, with being a Maori and so being on the wild side when you compared with the other race, the ones running the show. It was sumpthin closely linked with that but damned if you could figure it. (74; emphasis added)

This excerpt is not the only one to mark a clear paradigm shift from the individual to the collective. For instance, Jake's son, Abe, reflects on the ideas of transmission and legacy in some of the passages in parentheses which express his inner thoughts in the midst of an otherwise third-person narration: "(Violence claimed me. This is Jake's legacy.) " (Duff 2002, 170). However, two paragraphs later, the repetition of this statement introduces a change of scale from the individual to the collective: "([...] The collective, it always claims you. [...])" (171). So questions of individuality and subjectivity intermingle with questions of racial depictions of Māori and traits attributed to the whole community. Nevertheless, the collective is not entirely negative in these novels, and it may well be a solution to escape from essentialization and genetic determinism: in fact the links between individuals and their community are reasserted throughout the 
stories as a way of reclaiming one's forgotten or lost identity, while creating other cultural relations.

\section{Affiliation: towards the globalization of epistemological systems?}

8 Filiation and hereditary traits are rejected and feared as some kind of "epistemological localism," which denotes here a system of representation defining the characters according to the specific community or environment to which they belong. In Duff's books, it becomes clear that the characters have to break free from this very system of representation in which they are trapped. Their unwanted blood legacy is often associated with a gloomy fate, and experienced on a social level with the relegation of the Māori population to the margins of society and of the city. However, a new kind of relationship appears and takes over filial ties; it corresponds to the second process theorized by Edward Said, that of "affiliation," which is not a vertical relationship anymore but a horizontal one.

9 As Said linked the loss of the subject to the loss of filiative relationships, affiliation becomes the privileged way to reintegrate the individual into the community, to redirect the epistemological drive from the local and the personal to the global and general, and focus on the communities and their relationships: "The only other alternatives seemed to be provided by institutions, associations and communities whose social existence was not in fact guaranteed by biology, but by affiliation" (1983, 17). He further argues:

What I am describing is the transition from a failed idea or possibility of filiation to a kind of compensatory order that, whether it is a party, an institution, a culture, a set of beliefs, or even a world-vision, provides men and women with a new form of relationship, which I have been calling affiliation but which is also a new system. (19; emphasis added)

10 While in Duff's story, Jake is accepted in the Douglas clan as part of another whanau (which is already an extended family, going beyond the nuclear family as Westerners know it), in Mudrooroo's novel, that new relational system rests heavily on an extended sense of community and on a definition of culture as being transferable via experience. Consequently, culture itself is not as stable and hermetic as some of the Western essentialist definitions of culture would have it: as formulated by Margaret Jolly, in the article quoted above, following the "Western model," culture was "objectified and substantivized as a unitary essence" (1992, 59-60). One of the protagonists of Mudrooroo's tetralogy, Wadawaka, is from Africa but, as the scars on his body show, he has been adopted by the Aboriginal tribe, ${ }^{5}$ even though he keeps some of his own cultural specificities (for example his Dreaming Companion takes the shape of a leopard). He also is a former slave and he shares this experience of Western hegemony and domination with the tribe, which follows what Jolly says about how Pacific communities define cultural identity: "Indigenous Pacific constructs of cultural identity are permeable, situational, and shifting; shared identity derives from the shared experience of the environment, or shared behavior rather than shared substance" (59). That redefinition of cultural identity relies on two different, complementary movements since it becomes not only trans-tribal but also transnational. 
11 Aboriginal communities are well-known for being diverse, hundreds of them are scattered on the Australian territory. In Writing from the Fringe, Mudrooroo underlines this diversity of Aboriginal communities, mistakenly understood as just one people or one cultural group by Europeans, when he writes about "the different communities the Nangas, Nyoongahs, Djamadjis, Murris, Kooris, Yolngus and the other regional groups making up the unity of people placed under the white term, Aboriginal [...]" (1990, 3-4). This first misunderstanding of Aboriginal cultural diversity gives Mudrooroo ground for advocating and reclaiming it under the term "PanAboriginality." This redefinition of Aboriginality is also linked to a similar redefinition of Indigeneity itself, whose epistemological diversity has also come to be acknowledged. Yin C. Paradies says:

I am suggesting that we [...] recognize that although the poor and the rich Indigene, the cultural reviver and the quintessential cosmopolitan, the fair, dark, good, bad and disinterested may have little in common, they are nonetheless all equally but variously Indigenous. $(2006,363)$

This expansion from pan-Aboriginality to pan-Indigeneity makes it possible to find common ground with other communities from other continents - Africa as far as Mudrooroo's novels are concerned. These crossings and points of convergence between different black communities - Aboriginal, Māori and African - create a new zone of similar experience which could be called the "Black Pacific," to echo Paul Gilroy's "Black Atlantic." According to Gilroy, while "transcend[ing] both the structures of the nation state and the constraints of ethnicity and national particularity" $(1993,17)$, the Black Atlantic is a new way of "forging a new means to build alliances above and beyond petty issues like language, religion, skin colour, and to a lesser extent gender" (28). Affiliation deploys itself beyond national and ethnic borders and allows communities to expand their reach and empower themselves, by sharing the same struggles and political claims for example. ${ }^{6}$

Thus, one way of shifting epistemological paradigms is to focus again on the collective and the depiction of community even though, according to Said in his introduction to The World, the Text and the Critic, one of the dangers of affiliation is to repeat the filiative order:

Affiliation then becomes in effect a literal form of re-presentation, by which what is ours is good, and therefore deserves incorporation and inclusion in our programs of humanistic study, and what is not ours in this ultimately provincial sense is simply left out. [...] [T]his new affiliative structure and its systems of thought more or less directly reproduce the skeleton of family authority [...]. (1983, 21-22; second emphasis added)

Duff's and Mudrooroo's novels go further than this: to avoid the repetition of filiative authority through affiliation, they tend to raise and advocate collective awareness, the emergence of which derives from the redefinition of cultural community and contains a self-emancipatory dimension.

\section{Transcending affiliation: double-consciousness as emancipation}

13 In the essay quoted above, Said details the dependency of affiliation on filiation, while also introducing the role of criticism that he will come to develop later:

[W] hat I have been trying to show is that, as it has developed through the art and critical theories produced in complex ways by modernism, filiation gives birth to 
affiliation. Affiliation becomes a form of representing the filiative processes to be found in nature, although affiliation takes validated nonbiological social and cultural forms. $(1983,23)$

Said then focuses on the role of the contemporary critic, who can thus choose to follow two options: he calls the first alternative "organic complicity with the patterns [he has] described" (23), since the critic's work only helps legitimize those, whereas the second alternative leads the contemporary critic to

show how affiliation sometimes reproduces filiation, sometimes makes its own forms. Immediately, then, most of the political and social world becomes available for critical and secular scrutiny. (24)

The novels studied in this article seem to follow the second path devised by Said since they all offer direct examples of this "critical scrutiny": one of the consequences of the colonial subject being fragmented is paradoxically that it becomes self-reflexive, in so far as it starts pondering over its own existence, as well as the positioning of its community in the common space shared with white characters. From the very beginning of Duff's Once Were Warriors, even though she is but a young teenager, Grace shows an acute perception of New Zealand society's racial division and its imbalance in favour of the Pākehā, the white New Zealanders. As she is the one to accompany her brother Boogie to his trial, she reflects on the courtroom as one of the privileged places displaying white power, setting the tone for her relentless questioning of the partition of society: "Funny that, how one side of the double doors are one race, and the other this race: Maori. Made Grace want to crawl into a hole with shame. Or had her wanting to disassociate herself from them, jump up and explain..." (Duff 2004a, 24). Racial and social division is translated on a spatial and visual level by the doors of the courtroom, which set clear boundaries between those who judge, and those who are sentenced to jail. ${ }^{7}$ Division is thus not only about one's awareness of one's position in society, but it is about one's awareness of others' perception of oneself. This goes under the name of "double-consciousness" as defined by W.E.B. Du Bois:

[...] a sense of always looking at one's self through the eyes of others, of measuring one's soul by the tape of a world that looks on in amused contempt and pity. One ever feels his twoness, - an American, a Negro; two souls, two thoughts, two unreconciled strivings; two warring ideals in one dark body, whose dogged strength alone keeps it from being torn asunder. (Du Bois 2007, 8; emphasis added)

15 In the novels some characters seem to embody this concept and give allegorical or archetypal expression to it, since they too "look at themselves through the eyes of others." Duff often presents such episodes or even characters whose inner essence seems to be split into two "warring ideals," though not those of the "American" and the "Negro" as in Du Bois's theory, but rather those of the "New Zealander" and the "Māori," "two souls" which may not be that easily reconciled either. This leads to reflexions on the issue of self-definition that best finds its literary embodiment in split characters like the anonymous inmate in Jake's Long Shadow, the last volume of Duff's trilogy. This character, presented as "a voice" without a name since it "doesn't matter who [he is]" $(2002,163)$ first functions as an archetype of all inmates, representing the collective, but he also paradoxically comes to "voice" that "double-consciousness," which is finally the only thing that defines him for the reader. ${ }^{8}$ His words for his lot are rather harsh since he describes the inmates as being a "symptom," the "bogey hanging from the nose of society no one's prepared to point out. A wound that everyone closes eyes to" (163). As a consequence, one side of this two-sidedness is based on oblivion or erasure: society does not want to acknowledge such a level of debasement, and, since 
the inmates are murderers and rapists, such a level of ethical and moral failure, "most of [them] one race [Maori]" (164). In contrast to the situation described by Du Bois, this very refusal to define the prisoners and to acknowledge them "tears them asunder": "we're not only outcasts [...], we're cast aside in the too-hard-to-define tray. We're never going to be fixed" (164). The anonymous inmate however still feels this two-ness, except that society refuses to accept him as part of it, relegating him and his lot to a place where they could be disposed of and easily forgotten, the prison. Nevertheless, this prisoner feels this inner fragmentation and acknowledges it:

I am a definition of another type, I am. If you don't count the middle-aged dudes who go for ritual and symbolism, we're the crim types, who've seen the light of God. Only with me, I've seen my light, not God's.

It's one day waking up from a dream of seeing me. You! Screaming without the hot coal of truth on my skin. Screaming with the truth of Self bellowing it had never belonged to me, had Self, it had always been claimed by someone and something else. (167)

16 In this passage, the reader cannot but notice the confusing use of pronouns ("I," "we"), before that "I" strikingly becomes "You!," marking that transitional point where his awareness becomes a double-consciousness. For him, "Self ha[s] always been claimed by someone and something else," most likely by violence whereas the "light" he has seen is another side of himself, one that society will probably never be able to recognize or accept. This passage ends with that instance of self-awareness being translated into a literal self-awakening:

I woke up [...] and saw for the first time what and who I was surrounded by and that it had been me, we were one and the same, separated not by degrees, but here for the same reason and therefore existed as the same mindless creature. The creature that does not and cannot change. (167)

This character can be considered as an archetype of the idea of double-consciousness since he functions as an autonomous and separated element in most of the novel, ${ }^{9}$ while being acutely aware of the tension between this commonplace image of the violent Māori and the different person he finally comes to realize he could be.

While the inmate seems to fight against this definition imposed on his Self by society, another character, Jake "the Muss" (Duff 2004a, 23) is also constantly aware of the gaze of others: conversely, he tries to conform to those expectations in the hopes of gaining some kind of recognition. His nickname ("the Muss," for "muscle") emphasizes his pride in his physical strength, which he also voluntarily displays and uses for his own purposes. For example, he plays with the gaze of others: he greatly enjoys working on the road half naked, so that he can show off to the white people driving past him. If this passage first shows the extent of his ego, it nevertheless also implies that Jake is aware of the fact that he is but a "body" 10 to the whites, being "aware of people's awareness of him" (65), which could be understood as a translation in Duff's novel of Du Bois's expression "to look at themselves through the eyes of others." It seems that only by deliberately showing off this body will he ever be able to gain respect and admiration:

he could hear them, all day he could, in his mind saying to each other, Hey! Take a

look at that dude's build will you? So his head lifted in sweet prideful anticipation

of working all day shirtless and admired. It kinda felt like being loved. (13)

Jake positions himself as a consenting victim of this sort of ethnographic gaze, which may also recall the over-sexualized representation of Indigenous masculinity dating back to the nineteenth century and the racist fear of miscegenation. In Fear and Temptation, Terry Goldie dedicates a whole chapter to what he terms the "commodity of 
sexuality in the semiotic field of the indigene" $(1993,64)$ and he explains that complex intermingling of attraction and repulsion at the core of relations between Indigenous and white characters. However, the complexity of this event is revealed later in the narration since the reader is also given access to the other side's perception, that of Isobel and her friends who are slowed by the roadworks and get a good look at Jake:

One of the other girls commented that he was a handsome specimen and likened him to a thoroughbred horse, which I didn't quite go along with despite his body. A thoroughbred has a certain class. [...] I was reminded of white southern American women assessing a Negro slave. I felt somewhat disgusting for being one of them. (Duff 2004a, 160)

The encounter between the white women and Jake goes beyond that play on sexual attraction and repulsion since a historical layer is added to Isobel Trambert's interpretation of the scene, which has to be read in terms of racial tension. Racial difference is insisted upon when Isobel's friends liken Jake to a horse, in a comment that reaches back in time since Isobel also refers to the American slave trade, comparing Jake to an object with more monetary than human value. Racial difference and reification form a central node around which that fear of the over-sexualized Other evolves in the Western imagination according to Goldie: "It is as though the element of 'difference' provides a necessary catalyst for the process of individuation but, like other catalysts, it forms no part of the final product" $(1993,80)$. This is what happens: while Jake does everything he can to physically stand out, his difference sinks into generalization and even worse, into dehumanization. Instead of merely being part of a sexual balance of power, it is transferred onto a racial plane. One of Goldie's remarks concerning that fear of miscegenation - which was but the starting point of the analysis of this striking passage - could well be evoked here as well: when it comes to domination, race always prevails over sexual identity. As Goldie concludes, "The female white invader may become an invadee in terms of the sexual metaphor, but the balance of power remains a racial one" (81).

19 Moreover, while the Indigenous character is perceived as a commodity making the history of domination resurface in this episode, Isobel reaches another level of awareness for she seems to experience some kind of uncomfortable realization that those comments do not - and should not - really belong to the present situation but rather to another space and time - that of the slave trade. However, Isobel does not go as far as fully rejecting her friend's remark since she still forms part of that hierarchical system: not only does she comment on her own perception of a "thoroughbred" but she feels "disgusting for being one of them." Here, the use of the ing form instead of the -ed ending ("disgusted") insists even more on the inclusion of the white female character in that very system of domination which underpins the representation of the indigenous male character in the narration. As the choice of the word "disgusting" shows, Isobel comments on her own behaviour as if seeing herself from the outside and experiencing double-consciousness as well. Yet, even though she may become self-conscious in this episode, she does not really question her belonging to that group nor debunk its hierarchical system, which still defines her. On the narrative level, this passage is all the more striking as those colliding perceptions expose many different strata of consciousness, overlapping in the narration which finally becomes a layering of perceptions, interpretations and points of view. of his half-naked body - eludes him when the perceptions of the Pākehā women come 
to the fore. Indeed, Jake unconsciously plays by the Western epistemological system, as he finally acts according to the Pākehā women's expectations. He thus embodies what Bernard Perley describes in Performing Indigeneity, "the readily identifiable imagined mythic super Indigene [...] [the] charismatic Indigene" $(2014,52)$. Jake has come to accept and share this perception of his own self, reduced to his body, in order to exist gloriously, he thinks - in the white psyche. This is clearly explained in The Portrait of the Colonized, in which Albert Memmi severely condemns this type of scientific and racist discourse, warning against the vicious circle that he calls "the colonialist delusion" (2003, 175):

Constantly confronted with this image of himself, set forth and imposed on all institutions and in every human contact, how could the colonized help reacting to his portrait? It cannot leave him indifferent and remain a veneer which, like an insult, blows with the wind. He ends up recognizing it as one would a detested nickname which has become a familiar description. [...] Willfully created and spread by the colonizer, this mythical and degrading portrait ends up by being accepted and lived with to a certain extent by the colonized. It thus acquires a certain amount of reality and contributes to the true portrait of the colonized. (131-32)

Double-consciousness comes in Mudrooroo's novels together with barely hidden criticism on the part of the Aboriginal characters themselves, who are well aware of the white characters' representations, interpretations and aspirations, and this is what leads them to turn this double-consciousness into a self-defining practice. In The Promised Land, during Aboriginal ceremonies or corroborees, Aborigines wear body paintings representing European clothing, with as many details as possible, such as buttons on the jackets and even hats, made out of twigs. While secretly watching the dances, the missionary Sir George Augustus, also called Fada, relates what could be a good example of affiliation to mere mimicry and filiation, which, for him, becomes synonymous with assimilation, in this context: it reproduces colonial authority, since Aborigines wear European attire, and Fada can only read this as a tribute to Europeans and the recognition of the colonial order. It even leads him to say that assimilation has been successful with them and that they have become civilized:

Sir George Augustus, the well-known expert on the natives of the Great South Land, had always enjoyed their simple dances, especially those which employed mimicry. [...] [W] hat performances they did do would show the civilising process. (Mudrooroo 2000, 210)

The fact that the Aboriginal characters wear body paintings recalling European attire may first be interpreted as an instance of carnivalization with that reversal of roles, the fools becoming kings, the colonized becoming the colonizers. Travestying first appears in the outfits, in the distribution of ranks or identities that are not originally the characters', but while it definitely shows a wish for subversion, it also reasserts colonial power by acknowledging it. As Boaventura de Sousa Santos explains:

The carnivalization of emancipatory social practice has an important self-reflective dimension; it makes the decanonization and subversion of such practices possible. [...] In the feast, subversion is codified, in that it transgresses order while knowing the place of order and not questioning it. (Santos 2016, 61-62)

Even if it is not about a feast here but a corroboree, those outfits do not directly debunk white hegemony, but rather reassert it in acknowledging the colonial order that they have to follow and respect. However, Santos already mentions "the feast" as an "emancipatory social practice," implying that this practice also leads to something else. 
Indeed, the Aboriginal chief and shaman, Jangamuttuk, eventually repositions that European model as a cultural marker that they need to get rid of.

This transitional dimension is encapsulated in the ambiguity of the word "mimicry," which, in this passage, is the key to cultural misunderstanding. As the narration focuses on Fada's perception, "mimicry" becomes synonymous with mimesis, in the Aristotelian sense of the term - the unmediated and objective representation of reality. To him, the Aborigines, while imitating the Europeans, are merely copying reality, and this imitation is what leads him to believe that "the civilizing process," or assimilation, is well under way. However, this "mimicry" takes on another meaning for Jangamuttuk, who is not merely imitating or copying but performing, creating something else, with a specific purpose in mind. This kind of "mimicry" has a specific aim and, because of this intentional dimension, it becomes radically different from an instance of mimesis. As a consequence, the narration calls for a redefinition of the term "mimicry" insomuch as it points at the "parodic travestying" quality of Jangamuttuk's performance (Bakhtin 1981, 55). In fact, this instance of "mimicry" recalls what Bakhtin describes in The Dialogic Imagination as an "intentional dialogized hybrid" (76), which literally relies on the "appropriation, reworking and imitation of someone else's property, that is, of someone else's word" (77). If this performance is "dialogized," it is because it rests on heteroglossia since, during the corroboree, Jangamuttuk imitates Fada's way of talking as well as his accent and intonation: "[Fada and his wife, Mada] listened as on the wind came the voice of Jangamuttuk miming out perfectly words in the very voice of [Fada]. [...] Fada had rather enjoyed the mimicry. He took great pleasure in the natives and their simple, but effective ways." (Mudrooro 1991, 10).

Consequently, there is definitely something more to this corroboree that Fada fails to understand, which is Jangamuttuk's parodic intention behind that performance, turning it into an "intentional dialogized hybrid" to borrow Bakhtin's words. In such performances, discourse and reflexivity seem to prevail, according to Barbara Bolt:

To parody, ironise, or perform in a distorted way, suggests a model or category against which to perform. Through such strategies, the work of art becomes concerned with the manipulation of existing signs. Here matter, as material substance, seems to have disappeared into discourse. (2004, 153; emphasis added)

Those practices become discourses and testify to a degree of reflexivity on the part of the Aboriginal protagonists, which is linked to the emancipatory drive that was mentioned earlier since their body paintings become signs: "The men's head ornamentation also signified the European. [...] Their body painting had been designed to signify European fashion" (Mudrooroo 1991, 2-3; emphasis added). "Signify" implies the need for interpretation, also because those signs are to be read as "painted symbols" (13) - "thus replacing the reality for the symbolic." (2) Signs are associated with signification, and interpretation has to take place to create meaning, a process which in the novel could not be achieved by any Western character:

[F]or the moment there were [no Europeans eyes], and even if there had been, it was highly doubtful that the signifiers could have been read. What was the ultimate in a sign system, might still be read as primitive. (3)

The term "mimicry" may take on a postcolonial meaning, as it allows for a second reading and interpretation of the scene. As presented later on by Jangamuttuk himself, those ceremonies differ from mere mimicry since they are considered as real creations. As their "creator and choregrapher" (3; emphasis added), 
[Jangamuttuk] was not after a realist copy, after all he had no intention of aping the European, but sought for an adaptation of these alien cultural forms appropriate to his own cultural matrix. [...] There was a ritual need for it to be done. The need for an inclusion of these elements into a ceremony with a far different purpose than mere art. [...] Not only was he to attempt the act of possession but he hoped to bring all of his people into contact with the ghost realm so that they could capture the essence of health and well-being, and then break back safely into their own culture and society. (3-4, emphases added)

The goal in fact is a regeneration of Aboriginal people and culture: contamination can actually be seen as the first step to becoming immunized, and Jangamuttuk really aims at protecting his own tribe against the negative effects of colonization. This redefinition of mimicry may also recall what Homi Bhabha writes in The Location of Culture: he defines it as "almost the same but not quite" $(2004,123)$ while stressing the difference between mimesis and reality, which has definitely gone lost on Fada in Mudrooroo's novel: "What emerges between mimesis and mimicry is a writing, a mode of representation, that marginalizes the monumentality of history, quite simply mocks its power to be a model, that power which supposedly makes it imitable" (Bhabha 2004, 125; original emphasis). That idea of "writing" is what inscribes purpose or intention behind such an act, that "double vision" which finally often manages to debunk colonial power: "The menace of mimicry is its double vision which in disclosing the ambivalence of colonial discourse also disrupts its authority" (126). "Mimicry" eventually calls for the emancipation and redefinition of the identity of the colonized, and it is demonstrated on a cultural level: European elements are integrated into the Aboriginal cultural matrix and are finally used according to the effect that is sought for, more political than just merely artistic or aesthetic - as a self-defining and selfemancipatory practice.

In conclusion, the way indigenous subjectivity is depicted in these novels engages with and confronts the white characters' epistemological constructions of the Aboriginal and Māori communities: they show another way of understanding and knowing, which definitely inscribes them as postcolonial works, while integrating the issues they address in contemporary society and debates. Finally, Mudrooroo's and Duff's novels should be considered as reflexive as well: their capacity to rewrite the past while offering a reflexion on its very construction in the narration corresponds to one of the main attributes of what Linda Hutcheon calls "metafictional consciousness." She says: "to re-write or to re-present the past in fiction and in history is, in both cases, to open it up to the present, to prevent it from being conclusive and teleological" (2004, 110; emphasis added). Similarly, affiliation has to be understood as a synchronic as well as a diachronic process: it implies a return to the historical past while rooting reflexion in contemporary social and historical contexts - whether it be that of reading, writing or diegesis.

In the novels different layers overlap: histories intermingle, whether they be fictitious or alternative versions of Western history, without imposing one as more believable, or closer to reality than the others. The stories are not really about the different versions that are presented but rather about the way they are associated, coexist and made available in fiction. That epistemological dimension is always linked to an ontological questioning as in Mudrooroo's and Duff's novels, since it finally leads to the construction of the Indigenous subject thanks to the redefinition of their relation to a sense of community. This subjectivation process is not only a part of diegesis, it also feeds on the historical past of those communities that determined their position in a 
mostly white society, as well as their relation with Western characters for example. As a consequence, history, fiction and politics coalesce through the treatment of historical discourse but also through the reflexion on epistemological systems that underpin the novels: the combination of these two processes is the first step toward collective awareness, subjectivation and agency.

\section{BIBLIOGRAPHY}

BAKHTIN, Mikhail M. 1981. The Dialogic Imagination. Edited by Michael Holquist, translated by Caryl Emerson and Michael Holquist. Austin: University of Texas Press.

BHABHA, Homi K. 2004. The Location of Culture. 1994. London: New York, Routledge.

BOLT, Barbara. 2004. Art Beyond Representation: The Performative Power of the Image. London: I.B.

Tauris.

DU BoIs, William E. B. 2007. The Souls of Black Folk. 1903. New York: Oxford University Press.

DuFF, Alan. 2002. Jake's Long Shadow. Auckland: Vintage Books.

DuFF, Alan. 2004a. Once Were Warriors. 1990. Auckland: Vintage.

DuFF, Alan. 2004b. What Becomes of the Broken-Hearted? 1996. Milsons Point, NSW: Vintage.

GILROY, Paul. 1993. The Black Atlantic: Modernity and Double-Consciousness. London: Verso.

GOLDIE, Terry. 1993. Fear and Temptation: The Image of the Indigene in Canadian, Australian, and New Zealand Literatures. Montreal: McGill-Queen's University Press.

GRAHAM, Laura, and H. Glenn PENNY, eds. 2014. Performing Indigeneity: Global Histories and Contemporary Experiences. Lincoln: University of Nebraska Press.

HUTCHEON, Linda. 2004. A Poetics of Postmodernism: History, Theory, Fiction. 1988. Taylor and Francis. e-Library.

JOLLY, Margaret. 1992. “Specters of Inauthenticity.” The Contemporary Pacific 4, no.1: 49-72.

LAURIE, Victoria. 1996. "Identity Crisis.” Australian Magazine (20-21 July): 28-32.

MEMMI, Albert. 2003. The Colonizer and the Colonized. Translated by Howard Greenfeld. London: Earthscan. Originally published as Portrait du colonisé, précédé du Portrait du colonisateur (Paris : Buchet/Chastel, Corrêa, 1973).

MUDROOROO. 1990. Writing from the Fringe: a Study of Modern Aboriginal Literature. South Yarra, Melbourne: Hyland House.

MUDROOROO. 1991. Master of the Ghost Dreaming: A Novel. North Ryde, NSW: Angus \& Robertson.

MUdRooroo. 1998. The Undying. Pymble, NSW: Angus \& Robertson.

MUDROOROO. 1999. Underground. Pymble, NSW: Angus \& Robertson.

MudRooroo. 2000. The Promised Land. Pymble, NSW: Angus \& Robertson. 
PARADIES, Yin C. 2006. "Beyond Black and White: Essentialism, Hybridity and Indigeneity." Journal of Sociology 42, no. 4: 355-67.

PERLEY, Bernard. 2014. "Living Traditions: A manifesto for critical indigeneity." In Graham and Penny, 32-54.

PUNTER, David. 1998. Gothic Pathologies: The Text, the Body, and the Law. Basingstoke, London: Macmillan Press.

SAID, Edward W. 1983. The World, the Text, and the Critic. Cambridge: Harvard University Press.

SANTOS, Boaventura de Sousa. 2016. Epistemologies of the South: Justice Against Epistemicide. 2014. London: Routledge.

SHOEMAKER, Adam. 2003. "Mudrooroo and the Curse of Authenticity." In Mongrel Signatures: Reflections on the Work of Mudrooroo, edited by Annalisa Oboe, 1-23. Amsterdam: Rodopi. SINGEOT, Laura. 2014. “An Odyssey into the 'Black Pacific': A Reassessment of Mudrooroo's The Undying." Commonwealth Essays and Studies 37, no. 1: 89-99.

\section{NOTES}

1. For more details, see the first article in which this uncertainty was revealed: Victoria Laurie, "Identity Crisis," Australian Magazine, 20-21 July 1996, p. 28-32. For the detailed chronology of events and inquiry about Mudrooroo's identity, see Adam Shoemaker, "Mudrooroo and the Curse of Authenticity", in Annalisa Oboe (ed.), Mongrel Signatures: Reflections on the Work of Mudrooroo, Amsterdam: Rodopi, 2003, p.1-23.

2. A Pā is a Māori village.

3. In Mudrooroo's third book in the tetralogy, entitled Underground, the Aboriginal protagonist, George, understands that his father is Fada, the white missionary, and also feels contaminated or "stained" because of this "reversed" point of view on miscegenation $(1999,174)$.

4. In the 1990s a virulent debate took place amongst anthropologists about their different conceptions of Pacific cultures, and Pacific peoples' relation to culture. The specific conception of ethnicity mentioned here is to be opposed to the way others claimed Pacific peoples come to construct their identity as something that can be shared through experience. For more details, see Margaret Jolly's article, which retraces the history of this debate and gives a detailed account of the opposing sides and theories, as well as their evolution.

5. This term is used in the tetralogy.

6. For a detailed study of that shared trans-continental experience, see Singeot 2014.

7. The image of the trial has become a trope in postcolonial literature, relying on this spatial transfer of social and racial disparities, which also proves to be a recurrent theme throughout Duff's trilogy. Still in the first opus, for instance, Grace is used to spying on a Pākehā family at night from a tree: looking through the windows, she compares herself with the white girl, who is supposedly as old as her, observing in a way what she knows she could never be herself. Here the windows function like the double doors in the courtroom: a clear separation allowing the character to reflect upon its meaning in New Zealand society, and on her own position on the other side, the "deprived" side (Duff 2004a, 86). Those few passages take on a specific significance in Grace's tragedy - and in the whole novel - as she finally commits suicide, hanging herself from that very tree.

8. This character remains quite enigmatic and seems to give allegorical expression to such questions of identity and self-definition, even though the reader progressively understands that he is Jake's brother, Matti, serving time for murder. 
9. This transitional moment will lead him to do something good in his life and he will finally save Abe's life in prison.

10. The stress put on the Indigenous body here is not without recalling the racist ideology that relegated Indigenous people to their very physicality.

\section{ABSTRACTS}

Starting from Edward Said's The World, the Text and the Critic, in which he theorizes the cultural movements of filiation and affiliation, this article questions the epistemological links Alan Duff's and Mudrooroo's novels weave with European constructs of the Indigenous subject. This theoretical framework can be helpful in understanding the relations between the individual and the collective, mostly concerning their drive toward self-definition and emancipation.

\section{INDEX}

Keywords: filiation, affiliation, self-definition, collective awareness, metafiction

\section{AUTHOR}

\section{LAURA SINGEOT}

Institut Universitaire de Technologie de Cachan / CREA, Université Paris Nanterre Laura Singeot defended her PhD at the University of Paris Nanterre. Her dissertation deals with the representations of Indigeneity in Australia and New Zealand, focusing on Mudrooroo's tetralogy Master of the Ghost Dreaming and Alan Duff's trilogy Once Were Warriors, as well as artworks by Michael Cook and Tracey Tawhiao. She has published articles on Indigenous literatures, the representation of Australian history in contemporary Australian fiction, the anthropological gaze and its representation of Pacific communities in the nineteenth century, the integration of contemporary Indigenous art pieces in primarily "ethnographic" exhibitions, and the decolonization of writing in South Pacific Literature. 